\title{
Morphine-Induced c-fos mRNA Expression in Striatofugal Circuits: Modulation by Dose, Environmental Context, and Drug History
}

\author{
Susan M Ferguson ${ }^{1,4}$, Mark J Thomas ${ }^{2,4}$ and Terry E Robinson*,1,3 \\ 'Neuroscience Program, University of Michigan, Ann Arbor, MI, USA; ${ }^{2}$ Departments of Neuroscience and Psychology and Institute of Human \\ Genetics, University of Minnesota, Minneapolis, MN, USA; ${ }^{3}$ Department of Psychology, University of Michigan, Ann Arbor, MI, USA
}

\begin{abstract}
Opiates and psychostimulants produce many shared behavioral and neurobiological adaptations, such as behavioral sensitization and the induction of immediate early genes in the caudate-putamen (CPu). Previous studies indicate that factors such as dose, the environmental context surrounding drug administration and drug history can influence both morphine- and psychostimulant-induced behavioral sensitization. In addition, these factors can modulate the ability of psychostimulants to engage striatofugal circuits in the $\mathrm{CPu}$. The present study, therefore, sought to examine whether these factors have similar influences over the ability of morphine to engage corticostriatofugal circuits. We report that, when given in the home cage, morphine produced a small, but significant increase in the number of c-fos + striatonigral cells and c-fos + cells in cingulate cortex, but had no effect on the number of c-fos + striatopallidal cells. When given in a novel test environment, however, morphine dramatically increased the number of c-fos + striatonigral cells in a dose-dependent fashion, and this effect was maintained following repeated treatment. Unexpectedly, morphine treatment in a novel environment produced a dose-dependent reduction in the number of c-fos + striatopallidal cells and c-fos + cells in cingulate cortex, relative to exposure to novelty alone - effects that were reversed by repeated morphine treatment. We suggest that alterations in c-fos expression patterns in striatofugal circuits following morphine administration may be involved in drug-experience-dependent plasticity. Neuropsychopharmacology (2004) 29, I664-1674, advance online publication, 12 May 2004; doi: I 0. I038/sj.npp. 1300465
\end{abstract}

Keywords: dopamine; cingulate cortex; caudate nucleus; immediate early genes; in situ hybridization; rats

\section{INTRODUCTION}

Although drugs of abuse, such as opiates and psychostimulants, can vary in their initial molecular mechanisms of action, they share the ability to induce many behavioral and neurobiological adaptations. These shared adaptations are an important topic of study because, presumably, some subset of them forms the core processes that mediate addiction. One well-studied example of a shared adaptation between opiates and psychostimulants is behavioral sensitization-a progressive and persistent increase in the psychomotor response following repeated, intermittent drug exposure. Although the detailed molecular underpinnings of behavioral sensitization are not yet clear, one

\footnotetext{
*Correspondence: Dr TE Robinson, Department of Psychology (Biopsychology), The University of Michigan, 525 East University Avenue, Ann Arbor, MI 48I09-II09, USA, Tel: +| 734763 I304, Fax: + I 734763 7480, E-mail: ter@umich.edu

${ }^{4}$ These authors contributed equally to this work

Received 13 January 2004; revised 8 March 2004; accepted 17 March 2004

Online publication: 22 March 2004 at http://www.acnp.org/citations/ Npp032204040 I6/default.pdf
}

neurobiological adaptation that is thought to contribute to sensitization is the activation of immediate early genes (IEGs) in mesocorticolimbic brain regions, including the caudate-putamen ( $\mathrm{CPu}$; Nestler et al, 1993; Hyman and Malenka, 2001).

Previous studies have determined that several factors such as dose, the environmental context surrounding drug administration, and drug history can exert strong influences over the behavioral and IEG activation effects of psychostimulant drugs (Badiani et al, 1998; Ostrander et al, 2003; Uslaner et al, 2003a, b). For example, when given in a novel test environment, psychostimulants produce a larger acute response and more robust behavioral sensitization compared to drug administration in the home cage (Badiani et al, 1995a, b). These factors can also have a large impact on which subclasses of medium spiny projection neurons in the $\mathrm{CPu}$ are engaged (ie, show IEG expression) by psychostimulants. When given in the home cage, psychostimulants induce IEGs predominately in cells that coexpress mRNA for dopamine D1Rs, preprodynorphin, and preprotachykinin, and are part of the striatonigral pathway (Berretta et al, 1992; Cenci et al, 1992; Johansson et al, 1994; Ruskin and Marshall, 1994). When given in a novel test 
environment, however, psychostimulants also induce IEGs in cells that co-express mRNA for dopamine D2Rs and preproenkephalin and are part of the striatopallidal pathway (Jaber et al, 1995; Badiani et al, 1999; Uslaner et al, 2001).

The ability of morphine to induce psychomotor activation and promote behavioral sensitization is also modulated by factors such as dose, environmental context, and drug history (Badiani et al, 2000; Paolone et al, 2003). However, it is not yet known whether these factors have similar influences on which striatofugal circuits are engaged by morphine. To this end, we used dual in situ hybridization histochemistry to characterize the ability of morphine to induce one marker of neuronal activity, c-fos mRNA, in cells of the striatopallidal pathway, as a function of dose, environmental context and drug history. We report here that each of these factors influence the ability of morphine to engage the striatofugal circuits thought to be involved in drug experience-dependent behavioral plasticity.

\section{METHODS}

\section{Subjects}

Male Sprague-Dawley rats (Harlan Sprague Dawley, Indianapolis, IN) weighing 200-225 g upon arrival were housed individually in clear square plastic cages containing shredded paper bedding, and were given a one-week acclimation period prior to any experimental manipulation. The rooms were temperature- and humidity-controlled and maintained on a 14:10 h light: dark cycle, with food and water available ad libitum. All experimental procedures were approved by the University of Michigan Committee on the Use and Care of Animals.

\section{Drugs}

Morphine sulfate (University of Michigan Hospital, Ann Arbor, MI) was dissolved in sterile $0.9 \%$ saline and administered by intraperitoneal (i.p.) injection in a volume of $1 \mathrm{ml} / \mathrm{kg}$. Drug weight refers to the weight of the salt.

\section{Groups and Test Procedures}

Experiment 1: Morphine treatment in a novel test environment or in the home cage. Rats were randomly assigned to one of two groups ( $n=9-10 /$ group). One group of animals (Home) was transferred from the main animal colony to a testing room and placed individually into clear rectangular tubs $\left(8.5^{\prime \prime} \times 17.5^{\prime \prime} \times 9^{\prime \prime}\right)$ containing a clear plastic insert in the center of the cage $\left(2.5^{\prime \prime} \times 9^{\prime \prime} \times 9^{\prime \prime}\right)$ and ground corncob bedding on the floor. They remained in these cages for the duration of the experiment. Animals in the other group (Novel) remained in the main animal colony room. At 7 days after re-housing, Home groups received an i.p. injection of saline or morphine $(2.5,5$ or $10 \mathrm{mg} / \mathrm{kg}$ ) in their home cage (ie, the clear rectangular tubs). Animals in the Novel groups were transported to a testing room, where they received an injection of saline or morphine, and were then immediately placed into clear rectangular cages physically identical to those in which animals in the Home groups lived (but distinct from their own home cages). Behavior was recorded for $50 \mathrm{~min}$ and the total number of crossovers (defined by two consecutive beambreaks of sets of infrared photocells spaced $9^{\prime \prime}$ apart across the length of the tub) was used as an index of locomotor activity. At $50 \mathrm{~min}$ following injections, animals were decapitated and their brains were removed, frozen in isopentane and stored at $-70^{\circ} \mathrm{C}$.

Experiment 2: Repeated morphine treatment in a novel test environment. Rats were randomly assigned to one of two groups. During treatment, animals were transported daily to a testing room and placed in cages identical to those described in Experiment 1, where they received daily injections of saline or morphine $(10 \mathrm{mg} / \mathrm{kg}$, i.p.) for 9 consecutive days. Behavior was recorded for $120 \mathrm{~min}$ during each test session. Following a 14-day withdrawal period, saline- and morphine-treated rats were subdivided into groups and returned to the testing room, where they received a challenge injection of saline or morphine $(10 \mathrm{mg} /$ $\mathrm{kg})(n=7-9 /$ group). During the challenge test, behavior was recorded for $50 \mathrm{~min}$. At $50 \mathrm{~min}$ following injections, animals were decapitated and their brains were removed, frozen in isopentane and stored at $-70^{\circ} \mathrm{C}$.

\section{Dual In Situ Hybridization Methods}

The brains were sectioned using a cryostat and $16 \mu \mathrm{m}$ coronal sections were thaw-mounted onto Superfrost/Plus slides (Fisher Scientific, Pittsburgh, PA) and stored at $-70^{\circ} \mathrm{C}$ until processed for dual in situ hybridization (dISH). The method was a modification of that described by Curran and Watson (1995). Slides containing four tissue sections were processed using a ${ }^{35} \mathrm{~S}$-UTP and -CTP-labeled riboprobe complementary to c-fos mRNA (680-mer, courtesy of Dr T Curran, St Jude Children's Research Hospital, Memphis, TN) and a digoxigenin-UTP-labeled riboprobe complementary to preproenkephalin mRNA (693-mer, courtesy of Dr J Douglass, Amgen, Thousand Oaks, CA). The radioactive riboprobe was generated by incubating linearized c-fos DNA $(1 \mu \mathrm{g})$ at $37^{\circ} \mathrm{C}$ for $1.5 \mathrm{~h}$ in $1 \times$ transcription buffer, $100 \mu \mathrm{Ci}$ of $\alpha_{-}{ }^{35} \mathrm{~S}-\mathrm{UTP} \quad(100 \mathrm{Ci} / \mathrm{mM}$; $20 \mathrm{mCi} / \mathrm{ml}$; Amersham, Arlington Heights, IL), $160 \mu \mathrm{Ci}$ of $\alpha-{ }^{35} \mathrm{~S}-\mathrm{CTP}(800 \mathrm{Ci} / \mathrm{mM} ; 40 \mathrm{mCi} / \mathrm{ml} ;$ Amersham $), 400 \mu \mathrm{M}$ GTP, $400 \mu \mathrm{M}$ ATP, $8 \mathrm{mM}$ dithiothreitol (DTT), $10 \mathrm{U}$ RNase inhibitor, and $50 \mathrm{U}$ of T7 RNA polymerase. The nonradioactive riboprobe was generated by incubating linearized preproenkephalin DNA $(1 \mu \mathrm{g})$ at $37^{\circ} \mathrm{C}$ for $1.5 \mathrm{~h}$ in $1 \times$ transcription buffer, $320 \mu \mathrm{M}$ digoxigenin-UTP (dig-UTP; Boehringer, Manheim, Germany), $80 \mu \mathrm{M}$ UTP, $400 \mu \mathrm{M}$ GTP, $400 \mu \mathrm{M}$ ATP, $400 \mu \mathrm{M}$ CTP, $10 \mathrm{mM}$ DTT, $10 \mathrm{U}$ RNase inhibitor, and $50 \mathrm{U}$ of T7 RNA polymerase. The resulting probes were incubated at room temperature with $83 \mathrm{U}$ of RNase-free DNase for $15 \mathrm{~min}$ and then separated from free nucleotides on Micro Bio-Spin Chromatography columns (BioRad, Hercules, CA).

Prior to hybridization, tissue sections were fixed in $4 \%$ phosphate-buffered paraformaldehyde for $1 \mathrm{~h}$ at room temperature, rinsed three times in $2 \times \mathrm{SSC}$, placed into a solution of $0.1 \mathrm{M}$ triethanolamine $/ 0.25 \%$ acetic acid for $10 \mathrm{~min}$, rinsed in water and dehydrated in a series of graded 
alcohols (50-100\%). The ${ }^{35}$ S-labeled and dig-UTP-labeled probes were diluted in hybridization buffer $(50 \%$ formamide, $10 \%$ dextran sulfate, $3 \times$ SSC, $50 \mathrm{mM}$ sodium phosphate, $\mathrm{pH} 7.4,1 \times$ Denhardt's solution, and $10 \mathrm{mg} / \mathrm{ml}$ yeast tRNA) to give an approximate concentration of $3-4 \times 10^{6}$ d.p.m. $/ 80 \mu \mathrm{l}$ and $2.5 \mu \mathrm{l} / 80 \mu \mathrm{l}$, respectively. Slides were coverslipped with diluted probe $(80 \mu \mathrm{l})$ and placed in hybridization trays lined with filter paper dampened with $50 \%$ formamide $50 \%$ water. The trays were sealed and incubated at $55^{\circ} \mathrm{C}$ for $16 \mathrm{~h}$. Coverslips were floated off in $2 \times$ SSC and the slides were rinsed three times in $2 \times$ SSC. The slides were then incubated in RNase A $(200 \mu \mathrm{g} / \mathrm{ml})$ at $37^{\circ} \mathrm{C}$ for $1 \mathrm{~h}$, rinsed in $2 \times, 1 \times, 0.5 \times$, incubated in $0.1 \times$ SCC at $65^{\circ} \mathrm{C}$ for $1 \mathrm{~h}$, and then cooled to room temperature. The slides were rinsed in $0.1 \mathrm{M}$ sodium phosphate buffer ( $\mathrm{pH}$ 7.4), incubated with shaking for $1 \mathrm{~h}$ at room temperature in a blocking solution $(0.25 \%$ carageenan, $0.5 \%$ Triton-X, $0.1 \mathrm{M}$ sodium phosphate buffer), and then incubated overnight with shaking at room temperature with an antibody against digoxigenin, conjugated to alkaline phosphatase (sheep anti-dig AP, Fab fragments; Boehringer) that was diluted 1:10000 in a blocking solution. Slides were then incubated two times at room temperature with shaking ( $1 \mathrm{~h}$ each) in $0.1 \mathrm{M}$ sodium phosphate buffer, two times (30 min each) in Tris-buffered saline and rinsed in alkaline substrate buffer (ASB) $(100 \mathrm{mM}$ Tris base, $50 \mathrm{mM}$ $\mathrm{NaCl}, 50 \mathrm{mM} \mathrm{MgCl}_{2}, \mathrm{pH}$ 9.5). The color reaction was carried out in the dark at room temperature in ASB containing 5\% polyvinyl alcohol, $0.025 \%$ levamisole, and $2 \%$ NBT/BCIP (Boehringer). After $\sim 4 \mathrm{~h}$, the color reaction was stopped by washing the slides extensively in water, incubating in $0.1 \mathrm{M}$ glycine, $0.2 \%$ Triton $\mathrm{X}-100, \mathrm{pH} 2.2$ for $10 \mathrm{~min}$ at room temperature, and rinsing in water. Slides were then fixed in $2.5 \%$ glutaraldehyde for $2 \mathrm{~h}$, rinsed in water, and air-dried.

Slides were exposed to an X-ray film for 3-4 days (Kodak Biomax MR, Rochester, NY) and then dipped in emulsion (Ilford KD-5, Polysciences, Warrington, PA) and stored in light-tight boxes at $4^{\circ} \mathrm{C}$ for $17-21$ days. Slides were developed (Kodak D-19) for $2.5 \mathrm{~min}$ at $17^{\circ} \mathrm{C}$, rinsed in water, and fixed (Kodak Rapid Fix) for $5 \mathrm{~min}$ at $17^{\circ} \mathrm{C}$. Slides were then washed extensively in water, dehydrated in a series of graded alcohols (50-100\%), washed extensively in xylene, and coverslipped with Permount mounting medium.

Control experiments using sense probes or tissue pretreated with RNase A $\left(200 \mu \mathrm{g} / \mathrm{ml}\right.$ at $37^{\circ} \mathrm{C}$ for $\left.1 \mathrm{~h}\right)$ were performed to ensure probe specificity, and no binding was observed with either control.

\section{Quantification of Gene Expression and Data Analysis}

Initial quantification of c-fos mRNA expression was conducted on autoradiographs in multiple regions of the $\mathrm{CPu}$ across its entire rostrocaudal extent. The dorsomedial portion of the $\mathrm{CPu}$ at levels $0.0 \mathrm{~mm}$ to bregma and $0.4 \mathrm{~mm}$ posterior to bregma (see Figure 1; Paxinos and Watson, 1998) was selected for further analysis because, consistent with previous reports, the magnitude of c-fos expression induced by morphine was the greatest in this region. Cingulate cortex was also quantified at these levels (see Figure 1) because this region of frontal cortex is a major

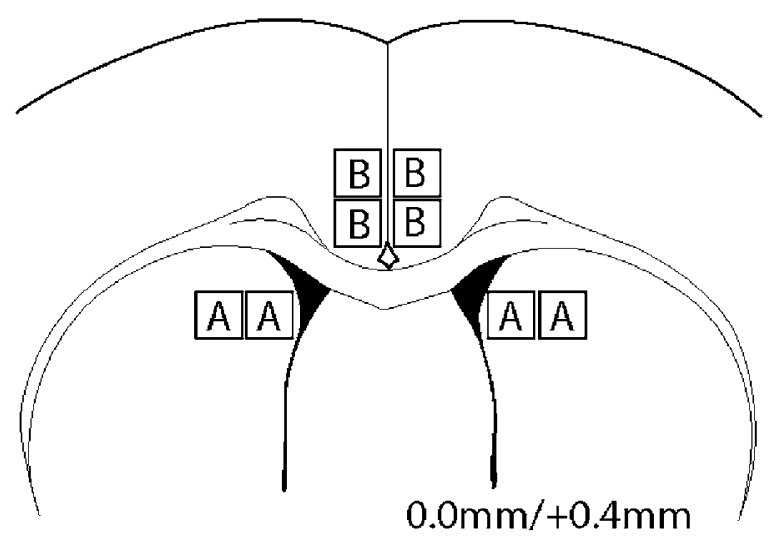

Figure I Illustration of a coronal section showing the regions in the CPu and cingulate cortex that were quantified. The boxes labeled ' $A$ ' represent the area of the dorsomedial CPu where the number of single-labeled cfos + and Enk + cells and the number of double-labeled c-fos/Enk + cells was counted. The boxes labeled 'B' represent the area of cingulate cortex where the number of single-labeled c-fos + cells was counted. Cell counts for each region were averaged across two levels $(0.0 \mathrm{~mm}$ and $0.4 \mathrm{~mm}$ from bregma) to give a total area of $1 \mathrm{~mm}^{2}$.

source of glutamatergic input into the dorsomedial $\mathrm{CPu}$ (Spencer, 1976; Girault et al, 1986; McGeorge and Faull, 1989). Quantification was carried out by an experimenter blind to the experimental conditions at $20 \times$ magnification using a Leica microscope (Letiz DMR, Wetzler, Germany) on sections from 7-10 animals/group. The total number of single- and double-labeled cells in the dorsomedial $\mathrm{CPu}$ and single-labeled cells in cingulate cortex were counted in two $250 \mu \mathrm{m}^{2}$ grids in each hemisphere at each level (for a total of four grids/region/level; see Figure 1). Cell counts for a given region were averaged across the two levels. ${ }^{35} \mathrm{~S}$-labeled cells (containing c-fos mRNA) appeared as silver grains under darkfield conditions and dig-labeled cells (containing preproenkephalin mRNA) appeared as purple precipitate under brightfield conditions (see Figure 3). Only ${ }^{35}$ S-labeled cells that contained dense clusters of silver grains (ie, at least 10 silver grains/cell) and dig-labeled cells that were uniformly darkly stained (ie, at least 10 times above background staining) were considered to be positively labeled. The total number of preproenkephalin mRNA-positive cells did not differ across groups (data not shown).

The majority of cells in the $\mathrm{CPu}$ are medium spiny projection neurons that either co-express mRNA for dopamine D2 receptors and preproenkephalin and are part of the striatopallidal pathway (these will be called Enk + cells) or co-express mRNA for dopamine D1 receptors, preprodynorphin and preprotachykinin and are part of the striatonigral pathway (these will be called Enk- cells). For example, we have found that under our in situ conditions, preproenkephalin mRNA and preprotachykin mRNA colocalize in only $4 \%$ of cells in the CPu (Uslaner et al, 2003a). Morphine reportedly induces c-Fos in very few interneurons in the $\mathrm{CPu}$ (Garcia and Harlan, 1997; Garcia et al, 2003), and therefore, in the present study, the number of c-fos/Enk + cells was subtracted from the total number of c-fos + cells in the $\mathrm{CPu}$ for each animal to give the number of c-fos/ Enk- cells. This number was then used as an indication of 
the number of cells in the striatonigral pathway that were activated following each treatment.

\section{Statistical Analysis}

For Experiment 1, group differences in locomotor activity and the number of c-fos + cells were tested using planned $t$ tests, one-way analyses of variances (ANOVA) followed by Dunnett's post-hoc tests or two-way ANOVA followed by Bonferroni's post-hoc tests. Relationships between variables were analyzed using Pearson correlation coefficients. For all comparisons, $\alpha<0.05$.

For Experiment 2, group differences in locomotor activity during treatment were tested using two-way repeatedmeasures ANOVA followed by Bonferroni's post-hoc tests, and within-group comparisons were made using paired $t$-tests. For the challenge data, group differences in locomotor activity and the number of c-fos + cells were analyzed using planned $t$-tests. Relationships between variables were analyzed using Pearson correlation coefficients. For all comparisons, $\alpha<0.05$.

\section{RESULTS}

\section{Experiment 1: Environmental Context and Dose Modulate Morphine-Evoked Psychomotor Activation and c-fos Expression}

The purpose of this experiment was to explore how dose and environmental context interact to influence the ability of a single, first injection of morphine (this will be referred to as an 'acute' injection) to modulate psychomotor activation and to engage specific cortico-striatofugal circuits.

Locomotor behavior. Figure 2 (panel a) depicts the effects of environmental context and dose on the ability of an acute injection of morphine to modulate locomotor activity during the first $50 \mathrm{~min}$ following treatment. When given in the home cage, morphine treatment did not alter locomotor activity compared to saline treatment, at any dose tested (Figure 2a; $\mathrm{F}_{3,23}=0.31, p=0.82$ ). Mere exposure to a novel environment increased locomotor activity compared to saline treatment in the home cage (Figure 2a; $t=3.57, p=0.003)$. Morphine administration in a novel test environment decreased this novelty-evoked locomotor activity in a dose-dependent fashion (Figure 2a; $\left.\mathrm{F}_{3,27}=5.93, p=0.003\right)$.

c-fos mRNA expression. Figure 2 (panels b-d) shows the effects of environmental context and dose on the ability of an acute injection of morphine to induce c-fos mRNA in cells of the cingulate cortex (panel b) and in cells of the $\mathrm{CPu}$ that are part of the striatopallidal pathway and express preproenkephalin mRNA (Enk + cells; panel d) or those cells that are part of the striatonigral pathway and do not contain preproenkephalin mRNA (Enk - cells; panel c). Figure 3 provides a representative example of a c-fos/Enk + dual in situ. As expected from previous studies, saline treatment in the home cage induced very few c-fos + cells. Therefore, this group was used as an index of basal levels of c-fos mRNA expression.

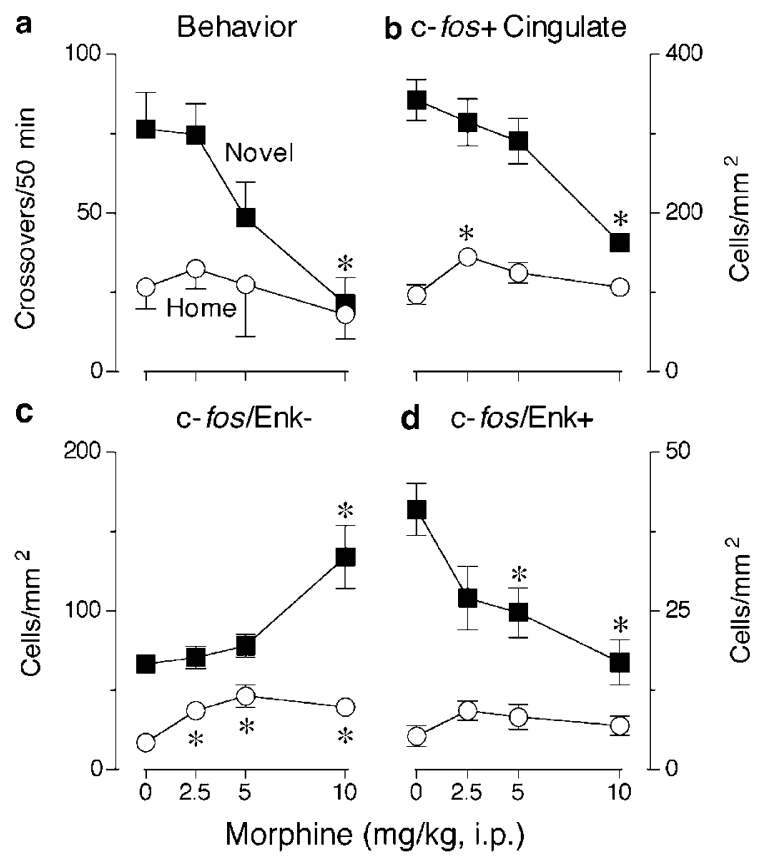

Figure 2 Dose and environmental context modulate morphine-induced locomotor activity and the number of c-fos + cells in cingulate cortex and in specific striatal cell populations. Black squares represent groups given morphine in a novel test environment and white circles represent groups given morphine in the home cage. (a) The mean ( \pm SEM) number of crossovers during the first $50 \mathrm{~min}$ following treatment. (b) The mean $( \pm$ SEM) number of c-fos + cells in cingulate cortex. (c) The mean ( \pm SEM) number of c-fos/Enk - cells in the CPu. (d) The mean ( \pm SEM) number of c-fos $/$ Enk + cells in the CPu. *, differs from $0 \mathrm{mg} / \mathrm{kg}(p<0.05$, one-way ANOVA followed by Dunnett's test).

When given in the home cage, only $2.5 \mathrm{mg} / \mathrm{kg}$ morphine significantly increased the total number of c-fos + cells in cingulate cortex above baseline (Figure $2 \mathrm{~b} ; \mathrm{F}_{3,27}=3.22$, $p=0.04$ ). In addition, morphine produced small, but significant increases in the number of c-fos/Enk- cells in the $\mathrm{CPu}$ (Figure $2 \mathrm{c} ; \mathrm{F}_{3,27}=5.91, p=0.003$ ), although the magnitude of this effect was not dose-dependent. There was no effect of morphine administration in the home cage on the number of c-fos/Enk + cells (Figure 2d; $\mathrm{F}_{3,27}=0.89$, $p=0.46)$.

Mere exposure to novelty significantly increased the total number of c-fos + cells in cingulate cortex above baseline (Figure $2 \mathrm{~b} ; t=12.02, p<0.0001$ ), and morphine produced a dose-dependent decrease in the number of these noveltyevoked c-fos + cells in cingulate cortex (Figure 2b; $\left.\mathrm{F}_{3,27}=9.28, p=0.0002\right)$. Mere exposure to novelty also significantly increased the number of c-fos/Enk - cells in the $\mathrm{CPu}$ (Figure 2d; $t=7.40, p<0.0001$ ), and morphine treatment in a novel environment produced a further dosedependent increase in the number of c-fos/Enk- cells (Figure $2 c ; F_{3,27}=8.13, p=0.0005$ ). Finally, exposure to a novel environment alone significantly increased the number of c-fos/Enk + cells in the $\mathrm{CPu}$ (Figure 2d; $t=7.52, p<0.0001$ ), but, in sharp contrast to the effect on Enk- cells, morphine treatment in a novel environment decreased the number of novelty-evoked c-fos/Enk + cells in a dose-dependent fashion (Figure 2d; $\mathrm{F}_{3,27}=5.55$, $p=0.004)$. 


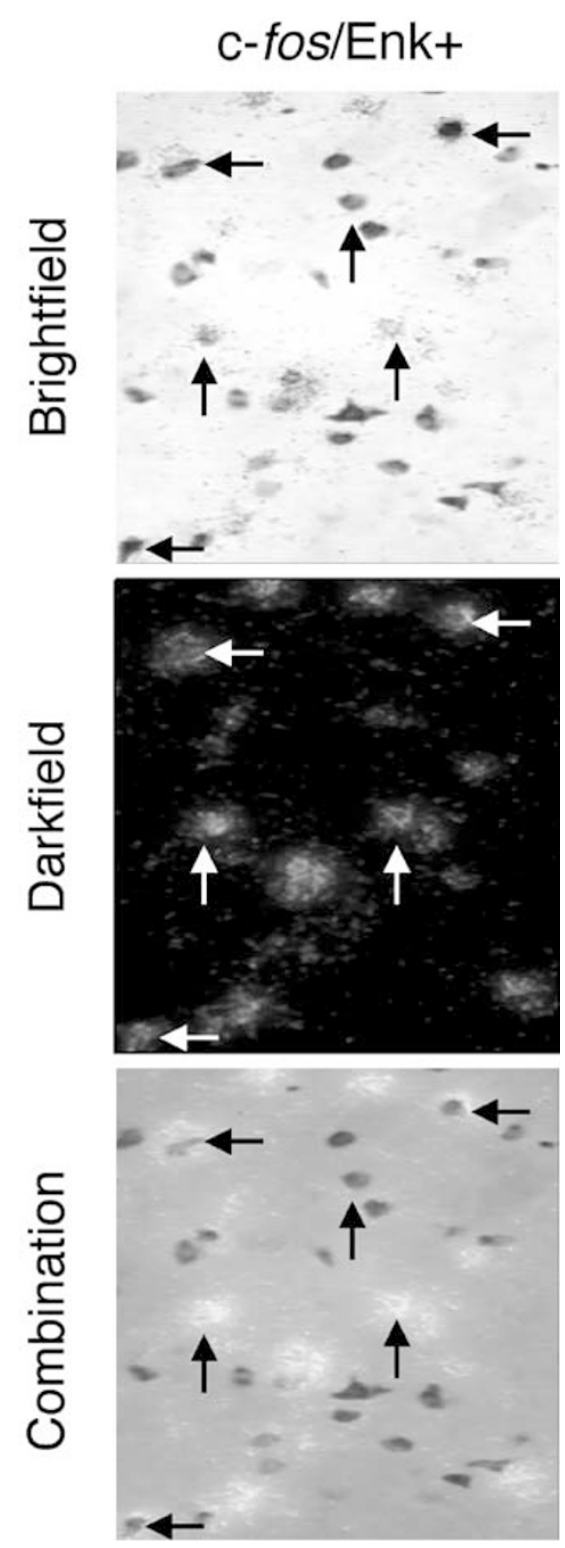

Figure 3 Representative histological plates depicting sections from the dorsomedial CPu that were double-labeled for c-fos mRNA and preproenkephalin mRNA. Sections were taken from an animal that received repeated morphine treatment $(10 \mathrm{mg} / \mathrm{kg}$, i.p.) in a novel test environment, followed by a |4-day withdrawal period and a morphine challenge $(10 \mathrm{mg} / \mathrm{kg}$, i.p.). (Top) Brightfield image in which Enk + cells are indicated by purple precipitate. (Middle) Darkfield image in which c-fos + cells are indicated by clusters of silver grains. (Bottom) Overlay of brightfield and darkfield images. Up arrows indicated single-labeled cells $(c-f o s+$ or Enk +$)$. Left arrows indicate double-labeled cells (c-fos/Enk + ).

\section{Experiment 2: Drug History Modulates the Ability of Morphine to Produce Psychomotor Activation and Engage Specific Cortico-striatofugal Circuits}

We next examined the extent to which repeated, intermittent administration of morphine in a novel test environment - which induces robust psychomotor sensitization-engages specific cortico-striatofugal circuits.

Locomotor behavior. The locomotor response during the treatment phase of this experiment is illustrated in Figure 4.
There was a significant interaction in the number of crossovers summed over the entire 120 min test session between the treatment day and group factors (Figure 4a; $\left.\mathrm{F}_{1,34}=19.57, p<0.0001\right)$. Post-hoc tests revealed that there was no difference between animals given saline or morphine ( $10 \mathrm{mg} / \mathrm{kg}$, i.p.) on day 1 (Figure $4 \mathrm{a} ; t=0.56, p>0.05$ ), but there was a significant difference between these groups on day 9 (Figure $4 \mathrm{a} ; t=3.90, p<0.001$ ), due to an increase in locomotor response over days in the morphine-treated group and a decrease in the saline-treated group.

Figure 5 (panel a) shows the locomotor response to a challenge injection of saline or morphine $(10 \mathrm{mg} / \mathrm{kg}$, i.p.) administered 14 days following the last (9th) treatment injection. As there were no differences in either locomotor activity or c-fos expression between saline- and morphinetreated animals that were given a saline challenge, data from these two groups were pooled to form a single saline challenge control group (saline group; Figure 5, panels a-d). Similar to the results from Experiment 1, administration of morphine to saline-treated animals (acute morphine group) produced a significant decrease in locomotor activity, relative to the saline group (Figure $5 \mathrm{a} ; t=6.05, p<0.0001$ ). When morphine-treated animals were challenged with morphine (repeated morphine group), however, they responded with a significant increase in locomotor activity compared to the acute morphine group, confirming that this group was sensitized (Figure $5 \mathrm{a} ; t=3.66, p=0.002$ ).

In Experiment 1 and the challenge test of Experiment 2 we report that acute morphine administration in a novel test environment produces a decrease in locomotor activity compared to saline-treated animals. However, in the treatment phase of Experiment 2 we report that on Day 1 there is no difference in the locomotor response of animals given saline or morphine. In addition, on Day 9 of the treatment phase of Experiment 2, morphine-treated animals have a greater locomotor response than saline-treated animals, whereas in the challenge test of Experiment 2 there are no differences in locomotor activity between these groups. The apparent discrepancies in these findings can be attributed to the biphasic pattern of psychomotor activation elicited by morphine. Acute administration of $10 \mathrm{mg} / \mathrm{kg}$ morphine produces an initial depressant effect lasting approximately $60 \mathrm{~min}$, followed by an increase in locomotor activity (Figure $4 \mathrm{~b}$ ). Repeated administration of $10 \mathrm{mg} / \mathrm{kg}$ morphine produces both a tolerance to the initial locomotor depressant effect and sensitization to the locomotor stimulant effects (Figure 4c). In order to optimize conditions for studying mRNA expression, animals were killed 50 min following morphine administration during Experiment 1 and the challenge test of Experiment 2, and therefore, only the first phase of the locomotor response to morphine was captured.

$c$-fos $m R N A$ expression. Figure 5 (panels b-d) depicts the effects of repeated morphine treatment $(10 \mathrm{mg} / \mathrm{kg}$, i.p.) on the number of c-fos + cells in cingulate cortex (panel b) and the number of c-fos/Enk- cells (panel c) or the number of c-fos/Enk + cells (panel d) in the $\mathrm{CPu}$. Consistent with the results from Experiment 1, acute morphine treatment $(10 \mathrm{mg} / \mathrm{kg}$, i.p.) produced a significant decrease in the total number of $\mathrm{c}-f \circ s+$ cells in cingulate cortex compared to the saline group (Figure $5 \mathrm{~b} ; t=4.20, p=0.0003$ ). Repeated 

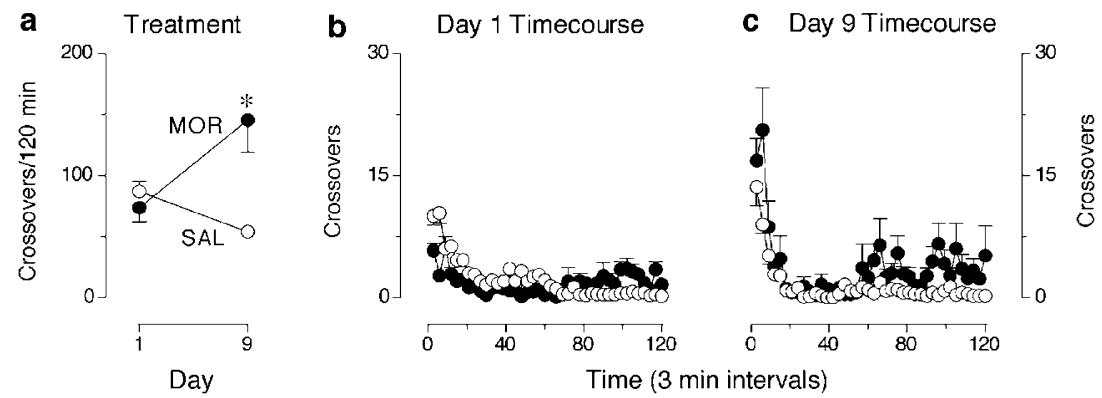

Figure 4 Repeated, intermittent exposure to morphine ( $10 \mathrm{mg} / \mathrm{kg}$, i.p.) produces locomotor sensitization. (a) The mean ( \pm SEM) number of crossovers summed over 120 min on day I and day 9 of treatment. (b) The mean ( \pm SEM) number of crossovers over time (3-min intervals) on day I. (c) The mean $( \pm$ SEM) number of crossovers over time (3-min intervals) on day 9. Animals given morphine (black circles) made significantly more crossovers on day 9 than animals given saline (white circles). *differs from saline ( $p<0.05$, two-way ANOVA, followed by Bonferroni's test).

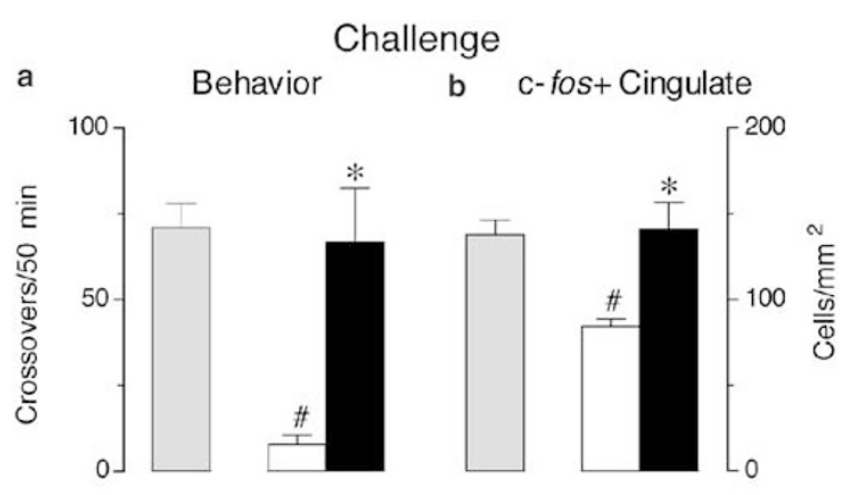

C

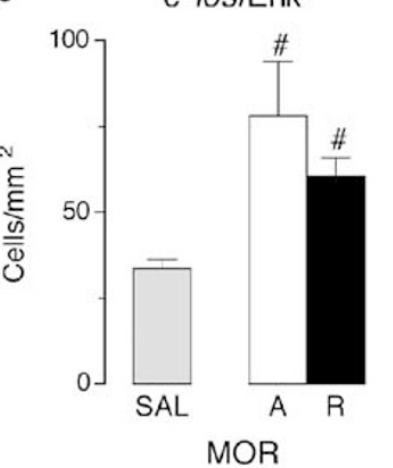

d c-fos/Enk+

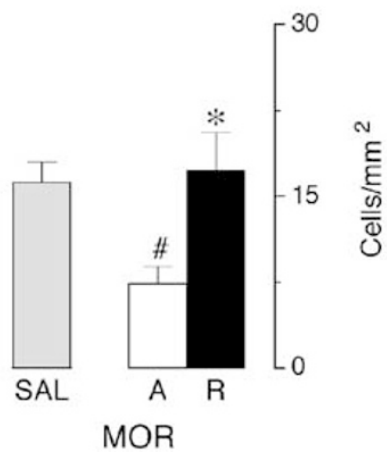

Figure 5 Drug history modulates morphine-induced locomotor activity and the number of c-fos + cells in cingulate cortex and in specific striatal cell populations. There were no differences between saline- and morphinetreated $(10 \mathrm{mg} / \mathrm{kg}$, i.p.) animals that were given a saline challenge (saline group), so these groups were combined (gray bars). White bars represent saline-treated animals given a morphine challenge $(10 \mathrm{mg} / \mathrm{kg}$, i.p.; acute morphine group) and black bars represent morphine-treated animals given a morphine challenge (repeated morphine group). (a) The mean ( \pm SEM) number of crossovers during the first 50 min following treatment. (b) The mean $( \pm$ SEM) number of c-fos + cells in cingulate cortex. (c) The mean ( \pm SEM) number of c-fos/Enk - cells in the CPu. (d) The mean ( \pm SEM) number of c-fos/Enk + cells in the CPu. *differs from the acute morphine group, ${ }^{\#}$ differs from the saline group $(p<0.05$, planned $t$-tests).

morphine treatment upregulated the total number of $\mathrm{c}$ fos + cells in cingulate cortex compared to the acute morphine group (Figure $5 \mathrm{~b} ; t=3.45, p=0.003$ ); however, there were no differences in the number of c-fos + cells in cingulate cortex compared to the saline group (Figure $5 \mathrm{~b}$; $t=0.19, p=0.85)$. Both acute and repeated morphine treatment significantly increased the number of c-fos/Enkcells in the $\mathrm{CPu}$ compared to the saline group (Figure $5 \mathrm{c}$; $t=3.86-5.09, p<0.001)$, but there were no differences in the number of c-fos/Enk - cells between these groups (Figure 5c; $t=1.06, p=0.3)$. Finally, similar to the results from Experiment 1, acute morphine treatment produced a significant decrease in the number of c-fos/Enk + cells compared to the saline group (Figure $5 \mathrm{~d} ; t=3.19$, $p=0.004)$. However, repeated morphine treatment upregulated the number of c-fos/Enk + cells compared to the acute morphine group (Figure $5 \mathrm{~d}$; $t=2.74, p=0.01$ ), although there were no differences in the number of c-fos/Enk + cells compared to the saline group (Figure $5 \mathrm{~d} ; t=0.31, p=0.76$ ).

\section{Morphine-Induced Cortical Activation is Positively Correlated With Enk + Cell Activation}

Figure 6 illustrates the relationships between morphineinduced cortical activation (ie, the number of c-fos + cells in cingulate cortex) and morphine-induced activation of either the striatonigral pathway (ie, the number of c-fos/ Enk - cells; top panels) or the striatopallidal pathway (ie, the number of c-fos/Enk + cells; bottom panels). In all conditions, cortical activation was positively and significantly correlated with activation of the striatopallidal pathway (Dose $\times$ Environment: panel e (home groups), $r=0.79 ; \quad p<0.0001 ;$ panel $\mathrm{f}$ (novel groups), $r=0.72$; $p<0.0001$; Drug History: panel g, $r=0.86 ; p<0.0001$ ). There were no significant correlations between cortical activation and activation of the striatonigral pathway (Dose $\times$ Environment: panel a (home groups), $r=0.21$; $p=0.31$; panel b (novel groups), $r=-0.30 ; p=0.17$; Drug History: panel $c, r=-0.01 ; p=0.98)$.

\section{Morphine-Induced Psychomotor Activation is Positively Correlated with Activation of Enk + Cells}

Figure 7 illustrates the relationships between morphineinduced locomotor activity (ie, the number of crossovers) and morphine-induced activation of either the striatonigral pathway (ie, the number of c-fos/Enk - cells; top panels) or the striatopallidal pathway (ie, the number of c-fos/Enk + cells; bottom panels). In all conditions, there were significant positive correlations between locomotor activity and activation of the striatopallidal pathway (Dose $x$ Environment: panel e (home groups), $r=0.55 ; p=0.01$; 

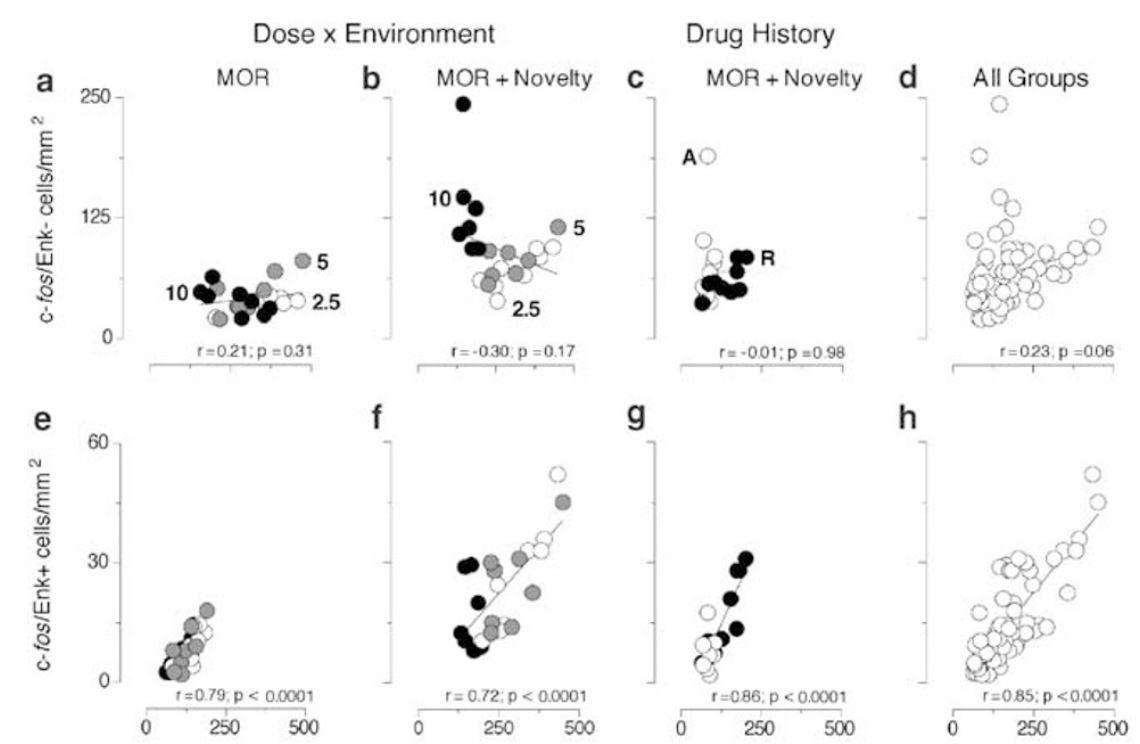

c-fos+ Cinqulate cortex cells $/ \mathrm{mm}^{2}$

Figure 6 Morphine-induced cortical activation is positively correlated with activation of the striatopallidal pathway. Relationships between the number of morphine-evoked c-fos + cells in cingulate cortex ( $x$ axes) and the number of morphine-evoked c-fos/Enk- cells ( $y$ axes, top panels) or the number of morphine-evoked c-fos/Enk + cells ( $y$ axes, bottom panels) as a function of dose (panels a, b, e, f: 2.5 (white circles), 5 (gray circles), and I0 (black circles) $\mathrm{mg} / \mathrm{kg}$ morphine), environmental context (panels a, b, e, f: morphine administration in the home cage (MOR) and morphine administration in a novel test environment (MOR + novelty)), and drug history (panels $c$, g: acute morphine treatment ( $A$; white circles) and repeated morphine treatment (R; black circles)).
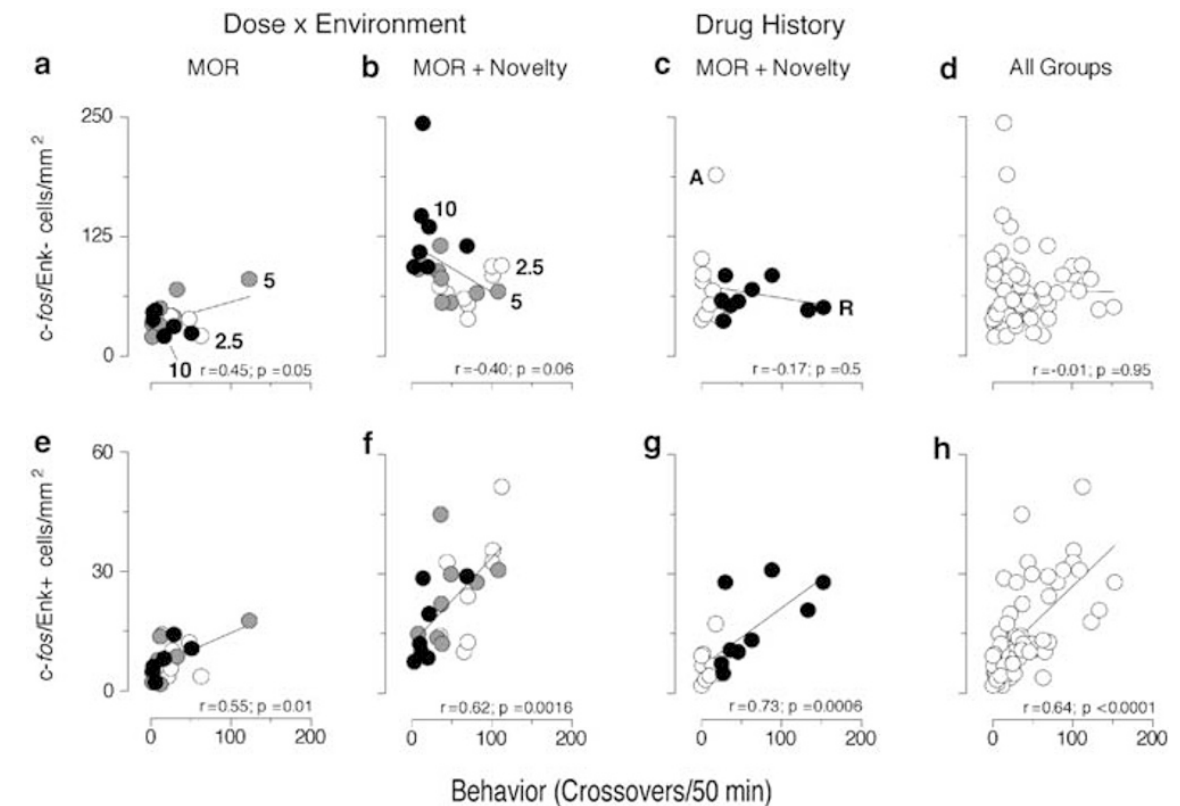

Behavior (Crossovers/50 min)

Figure 7 Morphine-induced psychomotor activation is positively correlated with activation of the striatopallidal pathway. Relationship between the number of morphine-induced crossovers ( $x$ axes) and the number of morphine-evoked c-fos/Enk- cells ( $y$ axes, top panels) or the number of morphineevoked c-fos/Enk + cells (y axes, bottom panels) as a function of dose (panels a, b, e, f: 2.5 (white circles), 5 (gray circles), and I0 (black circles) mg/kg morphine), environmental context (panels $a, b, e, f:$ morphine administration in the home cage (MOR) and morphine administration in a novel test environment (MOR + Novelty)), and drug history (panels c, g: acute morphine treatment ( $A$; white circles) and repeated morphine treatment (R; black circles)).

panel $\mathrm{f}$ (novel groups), $r=0.62 ; p=0.0016$; Drug History: panel g, $r=0.73 ; p=0.0006)$. There were no significant correlations between locomotor activity and activation of the striatonigral pathway (Dose $\times$ Environment: panel a (home groups), $r=0.45 ; p=0.05$; panel $\mathrm{b}$ (novel groups), $r=-0.40 ; p=0.06$; Drug History: panel c, $r=-0.17$; $p=0.5)$.

\section{DISCUSSION}

The present study examined how three factors, dose, the environmental context surrounding drug administration, and drug history influence the ability of morphine to induce c-fos + cells in the $\mathrm{CPu}$ and cingulate cortex. Our results demonstrate that each of these factors has a strong influence 
on which cortico-striatofugal circuits are engaged by morphine. When given in the home cage, morphine produced a small, but significant, increase in the number of c-fos + striatonigral cells and c-fos + cells in cingulate cortex, but had no effect on the number of $c-f o s+$ striatopallidal cells. When given in a novel test environment, morphine dramatically increased the number of cfos + striatonigral cells in a dose-dependent fashion, and this effect was maintained following repeated treatment. Unexpectedly, morphine treatment in this condition led to a dose-dependent reduction in the number of c-fos + striatopallidal cells and c-fos + cells in cingulate cortex, relative to exposure to novelty alone-effects that were reversed by repeated morphine treatment.

\section{Morphine-Induced c-fos Expression in the Striatopallidal Pathway may be Regulated by Glutamatergic Afferents from Frontal Cortex}

The general pattern of immediate early gene (IEG) expression elicited by morphine in the present study (eg, c-fos induction primarily in the most dorsomedial portion of the $\mathrm{CPu}$ and cingulate cortex) is consistent with the existing literature (Liu et al, 1994; Garcia et al, 1995; Curran et al, 1996; Erdtmann-Vourliotis et al, 1999b; Frankel et al, 1999b; see Harlan and Garcia (1998) for review). Our results are also consistent with a recent report showing that morphine administration in a stressful environment induces greater c-fos expression in the dorsomedial $\mathrm{CPu}$ than morphine administration in a calm environment (Mayer et al, 2002). Our work extends these previous reports by determining which populations of medium spiny projection neurons are engaged by morphine as a function of dose, the environmental context surrounding drug administration and drug history.

Studies examining the mechanisms underlying morphineevoked IEG expression in the CPu have established that coactivation of $\mu$ opioid and dopamine receptors is required for IEG induction to occur (Liu et al, 1994; Sharp et al, 1995; Bontempi and Sharp, 1997; Frankel et al, 1999a). Morphine is thought to act at $\mu$ opioid receptors to disinhibit mesolimbic dopamine neurons, resulting in increased dopamine release in the $\mathrm{CPu}$ (Matthews and German, 1984; Di Chiara and North, 1992; Johnson and North, 1992; Spanagel et al, 1992; Devine et al, 1993). Dopamine is then thought to induce IEG expression via D1 receptor activation of the cAMP/PKA signaling cascade (Lovenberg et al, 1991; Cole et al, 1994; Konradi et al, 1994, 1996). In addition, the ability of morphine to induce IEGs is strongly regulated by glutamate, as NMDA receptor antagonists (Liu et al, 1994; Bontempi and Sharp, 1997; D’Souza et al, 1999), AMPA receptor antagonists (Garcia et al, 2003), and metabotropic glutamate receptor antagonists (Garcia et al, 2003) all attenuate morphine-evoked IEG expression in the $\mathrm{CPu}$.

The source of glutamatergic regulation of morphineinduced IEG expression in specific striatal cell populations has not been established. A likely candidate is the frontal cortex, as this region has strong glutamatergic connections to the dorsomedial CPu (Spencer, 1976; Girault et al, 1986; McGeorge and Faull, 1989). Using c-fos as a marker of neuronal engagement, we examined the relationships between morphine-induced activation of cingulate cortex and morphine-induced activation of both striatal cell populations. We found a strong positive correlation between morphine-induced cingulate cortex activation and activation of Enk + cells, suggesting that the frontal cortex is a source of glutamatergic regulation of the striatopallidal pathway. Consistent with this idea, stimulation of corticostriatal afferents preferentially engages Enk + cells in the $\mathrm{CPu}$, an effect that is blocked by glutamate receptor antagonists (Berretta et al, 1997; Parthasarathy and Graybiel, 1997; Sgambato et al, 1997).

On the other hand, there was no correlation between morphine-induced cingulate cortex activation and activation of Enk - cells, suggesting that cortical regulation of IEG expression in the striatum may be specific to the striatopallidal pathway. It is not yet clear what is responsible for glutamatergic regulation of IEG expression in the striatonigral pathway. One possibility is that this occurs via thalamic glutamatergic inputs to the $\mathrm{CPu}$. This idea is supported by the finding that intrathalamic infusion of a $\mu$ opioid receptor antagonist decreases the ability of acute morphine treatment (which only engages Enk- cells) to induce c-Fos expression in the CPu (Frankel et al, 1999a). Further studies are necessary to confirm these roles of cortical and thalamic afferents in modulation of morphineevoked IEG expression in the $\mathrm{CPu}$.

\section{Morphine Induces a Different Pattern of Gene Expression in the Striatopallidal Pathway than that of Psychostimulants}

We have previously shown that manipulating factors such as dose, the environmental context surrounding drug administration, and drug history can strongly influence which striatofugal circuits are engaged by psychostimulant drugs (Badiani et al, 1999; Uslaner et al, 2001, 2003a, b). For example, psychostimulant administration in a novel test environment produces a dose-dependent increase in c-fos expression in Enk- cells compared to novelty alone (Uslaner et al, 2003a,b), and this increase in c-fos expression is maintained following repeated treatment and extended withdrawal (Uslaner et al, 2003a). The present study shows that morphine administration in a novel test environment also induces this pattern of striatonigral cellular activation. Although the mechanism of this activation in either case is not yet clear, the fact that antagonists of either dopamine or glutamate receptors block both morphine- and psychostimulant-evoked c-fos expression in Enk- cells (Liu et al, 1994; Ferguson et al, 2003) suggests that this regulation may be occurring through a common mechanism.

In contrast, there are some significant differences in c-fos expression in Enk + cells elicited by these two classes of drugs of abuse. For example, morphine treatment in a novel test environment leads to a dose-dependent decrease in novelty-evoked c-fos expression in Enk + cells in the CPu, an effect that is reversed by repeated morphine treatment. By contrast, psychostimulants show a different profile of cfos activation in Enk + cells. Although high doses of amphetamine (but not cocaine) given in a novel test environment have a similar inhibitory effect on c-fos expression as does morphine (Uslaner et al, 2003a,b), low 
to moderate doses of either amphetamine or cocaine increase c-fos expression in Enk + cells (Uslaner et al, 2001, 2003a,b), an effect that is maintained following repeated treatment and extended withdrawal (Uslaner et al, 2003a).

What might explain the opposing effects of morphine and psychostimulants on Enk + cell activation? Given the hypothesized role of corticostriatal afferents as an important modulator of striatopallidal activity, one possibility is that these opposing effects are due to differential drug actions on cortical activity and subsequent striatal glutamate release. Acute administration of morphine, which decreases the number of novelty-evoked c-fos/Enk + cells, concomitantly decreases the number of novelty-evoked cfos + cells in cingulate cortex, as well as firing of cortical neurons (Giacchino and Henriksen, 1996, 1998) and corticostriatal glutamate release (Desole et al, 1996; Nicol et al, 1996). By contrast, at doses that activate Enk + cells, psychostimulants increase novelty-evoked c-fos expression in cingulate cortex (Badiani et al, 1998) and stimulate corticostriatal glutamate release (Smith et al, 1995; Reid et al, 1997; Gray et al, 1999). Furthermore, transection of corticostriatal afferents leads to a selective blockade of psychostimulant-evoked c-fos expression in Enk + cells (SMF and TER unpublished observations). Similarly, repeated morphine treatment, which engages Enk + cells and upregulates the number of $\mathrm{c}-f \circ s+$ cells in cingulate cortex (compared to acute treatment), also upregulates striatal glutamate release (Desole et al, 1996). All of this evidence suggests that glutamatergic afferents from the cortex play an important regulatory role in activation of the striatopallidal pathway across drug classes.

\section{Is Striatal c-fos Expression Just a Consequence of Locomotor Activity?}

Acute psychostimulant treatment in a novel test environment results in marked psychomotor activation and c-fos expression in Enk + cells (Badiani et al, 1999; Uslaner et al, 2001), whereas acute administration of morphine has the opposite effect on locomotor activity and c-fos expression in Enk + cells. It is tempting to speculate, therefore, that c-fos expression in these studies is secondary to changes in locomotor activity. However, drugs that elicit large locomotor responses tend to induce weaker c-Fos expression in the $\mathrm{CPu}$ than drugs that elicit little to no locomotor responses (Erdtmann-Vourliotis et al, 1999a). And, in fact, in the present study, acute administration of $10 \mathrm{mg} / \mathrm{kg}$ morphine in a novel test environment evoked the greatest number of c-fos/Enk - cells in the $\mathrm{CPu}$, even though there was little locomotion in this group. These data suggest that striatal c-fos expression is not merely a reflection of ongoing locomotor activity, but may actually play a role in mediating that activity.

\section{The Ability of Morphine to Engage the Striatopallidal Pathway is Correlated with Psychomotor Activation}

Traditional models of basal ganglia function postulate that dopamine-mediated psychomotor activation occurs via concomitant excitation of the cortico-striatonigral pathway and inhibition of the cortico-striatopallidal pathway. This combination is proposed to have a net effect of inhibiting basal ganglia output nuclei, ultimately leading to disinhibition of the thalamus and consequent motor output (Albin et al, 1989; Gerfen et al, 1990; Gerfen, 1992). Based on these models, we would predict that in the present study there would be positive relationships between morphine-induced psychomotor activation and engagement of the striatonigral pathway and negative relationships between morphine-induced psychomotor activation and engagement of the striatopallidal pathway. This was not the case. Using c-fos as an indicator of neuronal engagement, we found no relationship between morphine-induced locomotor activity and activation of the striatonigral pathway, but a strong positive correlation between morphine-induced locomotor activity and activation of the striatopallidal pathway. Consistent with our results, morphine infused directly into the substantia nigra leads to a negative correlation between rotational behavior and cFos expression in the dorsomedial $\mathrm{CPu}$ (Bontempi and Sharp, 1997). These findings are also in agreement with recent reports that intrastriatal infusions of dopamine agonists, which increase locomotor activity, also increase neuronal firing in basal ganglia output nuclei (Waszczak et al, 2001, 2002), and that intravenous infusions of dopamine agonists, at doses that are sufficient to induce rotational behavior and increase c-Fos in both striatofugal pathways, did not decrease the firing rate of basal ganglia output nuclei (Ruskin et al, 1999).

The functional role(s) of alterations in IEG expression patterns in striatofugal circuits in morphine sensitization is not yet known. In the present study, acute morphine treatment led to activation of the striatonigral pathway, yet morphine did not elicit a locomotor response. The level of activation of the striatonigral pathway did not change as a function of drug history (ie, both acute and repeated morphine treatment led to the same level of activation), yet repeated morphine treatment results in behavioral sensitization. Importantly, acute morphine treatment also prevented activation of the striatopallidal pathway, an effect that was reversed by repeated morphine treatment. It should be noted, however, that repeated morphine treatment does not activate the striatopallidal pathway beyond that of saline controls, and therefore may reflect a tolerance to the acute inhibitory effects of morphine on this pathway. We propose that a threshold level of activation of the striatonigral pathway must be obtained for morphine sensitization to occur. Once this threshold is reached, activation of the striatopallidal pathway may become an important factor in the development of sensitization. Future studies targeted toward selective manipulations of these striatofugal circuits are necessary to confirm this hypothesis.

\section{ACKNOWLEDGEMENTS}

This research was supported by a NIDA grant to TER (R37 DA04294). TER was supported by a Senior Research Scientist Award (K05 DA00473), SMF by an Individual NRSA (F31 DA14737), and MJT by an Individual NRSA (F32 DA05945), all from NIDA. We thank Pengwei Yang for his assistance in conducting these experiments. 


\section{REFERENCES}

Albin RL, Young AB, Penney JB (1989). The functional anatomy of basal ganglia disorders. Trends Neurosci 12: 366-375.

Badiani A, Anagnostaras SG, Robinson TE (1995b). The development of sensitization to the psychomotor stimulant effects of amphetamine is enhanced in a novel environment. Psychopharmacology (Berl) 117: 443-452.

Badiani A, Browman KE, Robinson TE (1995a). Influence of novel versus home environments on sensitization to the psychomotor stimulant effects of cocaine and amphetamine. Brain Res 674: 291-298.

Badiani A, Oates MM, Day HE, Watson SJ, Akil H, Robinson TE (1998). Amphetamine-induced behavior, dopamine release, and c-fos mRNA expression: modulation by environmental novelty. J Neurosci 18: 10579-10593.

Badiani A, Oates MM, Day HE, Watson SJ, Akil H, Robinson TE (1999). Environmental modulation of amphetamine-induced c-fos expression in D1 versus D2 striatal neurons. Behav Brain Res 103: 203-209.

Badiani A, Oates MM, Robinson TE (2000). Modulation of morphine sensitization in the rat by contextual stimuli. Psychopharmacology (Berl) 151: 273-282.

Berretta S, Parthasarathy HB, Graybiel AM (1997). Local release of GABAergic inhibition in the motor cortex induces immediateearly gene expression in indirect pathway neurons of the striatum. J Neurosci 17: 4752-4763.

Berretta S, Robertson HA, Graybiel AM (1992). Dopamine and glutamate agonists stimulate neuron-specific expression of Fos-like protein in the striatum. J Neurophysiol 68: 767-777.

Bontempi B, Sharp FR (1997). Systemic morphine-induced Fos protein in the rat striatum and nucleus accumbens is regulated by mu opioid receptors in the substantia nigra and ventral tegmental area. J Neurosci 17: 8596-8612.

Cenci MA, Kalen P, Mandel RJ, Wictorin K, Bjorklund A (1992). Dopaminergic transplants normalize amphetamine- and apomorphine-induced Fos expression in the 6-hydroxydopaminelesioned striatum. Neuroscience 46: 943-957.

Cole DG, Kobierski LA, Konradi C, Hyman SE (1994). 6Hydroxydopamine lesions of rat substantia nigra up-regulate dopamine-induced phosphorylation of the cAMP-response element-binding protein in striatal neurons. Proc Natl Acad Sci USA 91: 9631-9635.

Curran EJ, Akil H, Watson SJ (1996). Psychomotor stimulant- and opiate-induced c-fos mRNA expression patterns in the rat forebrain: comparisons between acute drug treatment and a drug challenge in sensitized animals. Neurochem Res 21: $1425-1435$.

Curran EJ, Watson Jr SJ (1995). Dopamine receptor mRNA expression patterns by opioid peptide cells in the nucleus accumbens of the rat: a double in situ hybridization study. J Comp Neurol 361: 57-76.

D'Souza DN, Harlan RE, Garcia MM (1999). Sexual dimorphism in the response to $N$-methyl-D-aspartate receptor antagonists and morphine on behavior and c-Fos induction in the rat brain. Neuroscience 93: 1539-1547.

Desole MS, Esposito G, Fresu L, Migheli R, Enrico P, Mura MA et al (1996). Effects of morphine treatment and withdrawal on striatal and limbic monoaminergic activity and ascorbic acid oxidation in the rat. Brain Res 723: 154-161.

Devine DP, Leone P, Pocock D, Wise RA (1993). Differential involvement of ventral tegmental mu, delta and kappa opioid receptors in modulation of basal mesolimbic dopamine release: in vivo microdialysis studies. J Pharmacol Exp Ther 266: $1236-1246$.

Di Chiara G, North RA (1992). Neurobiology of opiate abuse. Trends Pharmacol Sci 13: 185-193.
Erdtmann-Vourliotis M, Mayer P, Linke R, Riechert U, Hollt V (1999b). Long-lasting sensitization towards morphine in motoric and limbic areas as determined by c-fos expression in rat brain. Brain Res Mol Brain Res 72: 1-16.

Erdtmann-Vourliotis M, Mayer P, Riechert U, Hollt V (1999a). Acute injection of drugs with low addictive potential (delta(9)tetrahydrocannabinol, 3,4-methylenedioxymethamphetamine, lysergic acid diamide) causes a much higher c-fos expression in limbic brain areas than highly addicting drugs (cocaine and morphine). Brain Res Mol Brain Res 71: 313-324.

Ferguson SM, Norton CS, Watson SJ, Akil H, Robinson TE (2003). Amphetamine-evoked c-fos mRNA expression in the caudateputamen: the effects of DA and NMDA receptor antagonists vary as a function of neuronal phenotype and environmental context. J Neurochem 86: 33-44.

Frankel PS, Garcia MM, Harlan RE (1999a). Infusion of beta-FNA into the thalamus attenuates morphine-induced c-Fos induction in the rat caudate putamen. Brain Res 838: 222-226.

Frankel PS, Harlan RE, Garcia MM (1999b). Chronic administration of morphine alters immediate-early gene expression in the forebrain of post-dependent rats. Brain Res 835: 204-212.

Garcia MM, Anderson AT, Edwards R, Harlan RE (2003). Morphine induction of $c$-fos expression in the rat forebrain through glutamatergic mechanisms: role of non- $n$-methyl-Daspartate receptors. Neuroscience 119: 787-794.

Garcia MM, Brown HE, Harlan RE (1995). Alterations in immediate-early gene proteins in the rat forebrain induced by acute morphine injection. Brain Res 692: 23-40.

Garcia MM, Harlan RE (1997). Neurochemical characterization of cortical and striatal neurons expressing c-Fos protein after acute morphine administration. Soc Neurosci Abstr 23: 1107.

Gerfen CR (1992). The neostriatal mosaic: multiple levels of compartmental organization. Trends Neurosci 15: 133-139.

Gerfen CR, Engber TM, Mahan LC, Susel Z, Chase TN, Monsma Jr FJ et al (1990). D1 and D2 dopamine receptor-regulated gene expression of striatonigral and striatopallidal neurons. Science 250: $1429-1432$.

Giacchino JL, Henriksen SJ (1996). Systemic morphine and local opioid effects on neuronal activity in the medial prefrontal cortex. Neuroscience 70: 941-949.

Giacchino JL, Henriksen SJ (1998). Opioid effects on activation of neurons in the medial prefrontal cortex. Prog Neuropsychopharmacol Biol Psychiatry 22: 1157-1178.

Girault JA, Barbeito L, Spampinato U, Gozlan H, Glowinski J, Besson MJ (1986). In vivo release of endogenous amino acids from the rat striatum: further evidence for a role of glutamate and aspartate in corticostriatal neurotransmission. J Neurochem 47: 98-106.

Gray AM, Rawls SM, Shippenberg TS, McGinty JF (1999). The kappa-opioid agonist, U-69593, decreases acute amphetamineevoked behaviors and calcium-dependent dialysate levels of dopamine and glutamate in the ventral striatum. J Neurochem 73: $1066-1074$.

Harlan RE, Garcia MM (1998). Drugs of abuse and immediateearly genes in the forebrain. Mol Neurobiol 16: 221-267.

Hyman SE, Malenka RC (2001). Addiction and the brain: the neurobiology of compulsion and its persistence. Nat Rev Neurosci 2: 695-703.

Jaber M, Cador M, Dumartin B, Normand E, Stinus L, Bloch B (1995). Acute and chronic amphetamine treatments differently regulate neuropeptide messenger RNA levels and Fos immunoreactivity in rat striatal neurons. Neuroscience 65: 1041-1050.

Johansson B, Lindstrom K, Fredholm BB (1994). Differences in the regional and cellular localization of c-fos messenger RNA induced by amphetamine, cocaine and caffeine in the rat. Neuroscience 59: 837-849. 
Johnson SW, North RA (1992). Opioids excite dopamine neurons by hyperpolarization of local interneurons. J Neurosci 12: 483-488.

Konradi C, Cole RL, Heckers S, Hyman SE (1994). Amphetamine regulates gene expression in rat striatum via transcription factor CREB. J Neurosci 14: 5623-5634.

Konradi C, Leveque JC, Hyman SE (1996). Amphetamine and dopamine-induced immediate early gene expression in striatal neurons depends on postsynaptic NMDA receptors and calcium. J Neurosci 16: 4231-4239.

Liu J, Nickolenko J, Sharp FR (1994). Morphine induces c-fos and junB in striatum and nucleus accumbens via D1 and $N$-methyl-Daspartate receptors. Proc Natl Acad Sci USA 91: 8537-8541.

Lovenberg TW, Nichols DE, Nestler EJ, Roth RH, Mailman RB (1991). Guanine nucleotide binding proteins and the regulation of cyclic AMP synthesis in NS20Y neuroblastoma cells: role of D1 dopamine and muscarinic receptors. Brain Res 556: 101-107.

Matthews RT, German DC (1984). Electrophysiological evidence for excitation of rat ventral tegmental area dopamine neurons by morphine. Neuroscience 11: 617-625.

Mayer P, Erdtmann-Vourliotis M, Riechert U, Ammon S, Hollt V (2002). Mild stress sensitizes the brain's response to morphine. Brain Res Mol Brain Res 104: 143-147.

McGeorge AJ, Faull RL (1989). The organization of the projection from the cerebral cortex to the striatum in the rat. Neuroscience 29: 503-537.

Nestler EJ, Hope BT, Widnell KL (1993). Drug addiction: a model for the molecular basis of neural plasticity. Neuron 11: 995-1006.

Nicol B, Rowbotham DJ, Lambert DG (1996). mu- and kappaopioids inhibit $\mathrm{K}+$ evoked glutamate release from rat cerebrocortical slices. Neurosci Lett 218: 79-82.

Ostrander MM, Badiani A, Day HE, Norton CS, Watson SJ, Akil H et al (2003). Environmental context and drug history modulate amphetamine-induced c-fos mRNA expression in the basal ganglia, central extended amygdala, and associated limbic forebrain. Neuroscience 120: 551-571.

Paolone G, Burdino R, Badiani A (2003). Dissociation in the modulatory effects of environmental novelty on the locomotor, analgesic, and eating response to acute and repeated morphine in the rat. Psychopharmacology (Berl) 166: 146-155.

Parthasarathy HB, Graybiel AM (1997). Cortically driven immediate-early gene expression reflects modular influence of sensorimotor cortex on identified striatal neurons in the squirrel monkey. J Neurosci 17: 2477-2491.

Paxinos G, Watson C (1998). The Rat Brain in Stereotaxic Coordinates, 4th edn. Academic: San Diego.

Reid MS, Hsu Jr K, Berger SP (1997). Cocaine and amphetamine preferentially stimulate glutamate release in the limbic system: studies on the involvement of dopamine. Synapse 27: 95-105.
Ruskin DN, Bergstrom DA, Mastropietro CW, Twery MJ, Walters JR (1999). Dopamine agonist-mediated rotation in rats with unilateral nigrostriatal lesions is not dependent on net inhibitions of rate in basal ganglia output nuclei. Neuroscience 91: 935-946.

Ruskin DN, Marshall JF (1994). Amphetamine- and cocaineinduced fos in the rat striatum depends on D2 dopamine receptor activation. Synapse 18: 233-240.

Sgambato V, Abo V, Rogard M, Besson MJ, Deniau JM (1997). Effect of electrical stimulation of the cerebral cortex on the expression of the Fos protein in the basal ganglia. Neuroscience 81: 93-112.

Sharp FR, Liu J, Nickolenko J, Bontempi B (1995). NMDA and D1 receptors mediate induction of c-fos and junB genes in striatum following morphine administration: implications for studies of memory. Behav Brain Res 66: 225-230.

Smith JA, Mo Q, Guo H, Kunko PM, Robinson SE (1995). Cocaine increases extraneuronal levels of aspartate and glutamate in the nucleus accumbens. Brain Res 683: 264-269.

Spanagel R, Herz A, Shippenberg TS (1992). Opposing tonically active endogenous opioid systems modulate the mesolimbic dopaminergic pathway. Proc Natl Acad Sci USA 89: 2046-2050.

Spencer HJ (1976). Antagonism of cortical excitation of striatal neurons by glutamic acid diethyl ester: evidence for glutamic acid as an excitatory transmitter in the rat striatum. Brain Res 102: $91-101$.

Uslaner J, Badiani A, Norton CS, Day HE, Watson SJ, Akil H et al (2001). Amphetamine and cocaine induce different patterns of c-fos mRNA expression in the striatum and subthalamic nucleus depending on environmental context. Eur J Neurosci 13: 1977-1983.

Uslaner JM, Crombag HS, Ferguson SM, Robinson TE (2003a). Cocaine-induced psychomotor activity is associated with its ability to induce c-fos mRNA expression in the subthalamic nucleus: effects of dose and repeated treatment. Eur J Neurosci 17: $2180-2186$.

Uslaner JM, Norton CS, Watson SJ, Akil H, Robinson TE (2003b). Amphetamine-induced c-fos mRNA expression in the caudateputamen and subthalamic nucleus: interactions between dose, environment, and neuronal phenotype. J Neurochem 85: 105-114.

Waszczak BL, Martin L, Boucher N, Zahr N, Sikes RW, Stellar JR (2001). Electrophysiological and behavioral output of the rat basal ganglia after intrastriatal infusion of d-amphetamine: lack of support for the basal ganglia model. Brain Res 920: 170-182.

Waszczak BL, Martin LP, Finlay HE, Zahr N, Stellar JR (2002). Effects of individual and concurrent stimulation of striatal D1 and D2 dopamine receptors on electrophysiological and behavioral output from rat basal ganglia. J Pharmacol Exp Ther 300: $850-861$. 